\title{
Measuring The Value of
} Experiential Learning

\section{Educators have long held that experiential learning is valuable. The issue here is the measurement of that value for all participants}

\section{by Chekitan S. Dev}

THE LECTURE METHOD of instruction frequently fails to capture the dynamics of the learning experience, particularly for such topics as marketing. The case method, while a substantial learning innovation, does not quite capture the richness of a business situation. For marketing and many other topics like it, the experiential approach seems to be effective.*

*See: K. Michael Haywood, "Students as Consultants: A New Alternative in Experiential Learning," Hospitality Education and Research Journal, 8, No. 1 (1983), pp. 69-84; and W.R. Wynd, "An Experiential Approach to Marketing Education," Journal of Marketing Education, Summer 1989, pp. 64-71.
In a recently revised marketing course, "Marketing Communication Media," I asked my students to apply marketing-communication tools to a real business situation. I expected that this experiential approach would benefit three groups: namely, the students, the businesses participating in the exercise, and Cornell University. In a departure from the usual method of conducting such a course, I used questionnaires to measure the value of the experience both to the students and to the businesses. The goal was to determine whether the experiential approach substantially increased the students' knowledge of marketing communication. In this article, I report on the questionnaire findings.

\section{The Assignment}

Marketing Communication Media is an elective course offered to seniors at the Cornell School of Hotel Administration. The first time the course was taught, the course material included

Chekitan S. Dev, Ph.D., is an assistant professor of marketing at the Cornell School of Hotel Administration. He was assisted in preparing this article by Kathleen Dennison, a candidate for the M.P.S. degree at the Hotel School. Funding for this study was provided by a grant from the Sears Roebuck Foundation, administered through Cornell's Office of Instructional Support. 


\section{Students and business owners were nearly unanimous in their enthusiasm for the experiential approach.}

industry examples, case studies, and mini-projects. The students responded so favorably to the projects that this component was greatly expanded when the course was offered the second time.

The 32 students in the course formed 16 two-person teams, each of which picked a business in the Ithaca area to be its "client." The teams worked through the semester to develop a marketing-communications plan for this client.

To assess the effectiveness of the assignment, three questionnaires were administered. The first, directed to the students at the beginning of the course, asked the students to rate their familiarity with ten marketingcommunication tools. The second questionnaire was administered to the students at the end of the semester. In addition to the same quantitative questions regarding the students' knowledge of marketing-communication tools, the second survey asked for qualitative responses to such questions as whether the students believed they had made a contribution to their clients' businesses and whether the project contributed to the students' understanding of the material presented in the course. The third questionnaire asked the business clients to rate the students' marketingcommunication plans and asked whether the students had made a contribution to the business.

\section{Passing Grades}

I expected that students' self-reported scores of practical familiarity with marketing communication would increase by the end of the course and that the class as a whole would report more knowledge of marketing communication. I also hypothesized that students and their clients would have similar qualitative assessments of the experiential element of the course.

Students' assessment. At the beginning of the course, the students' ratings of their knowledge of various marketing-communication tools ranged from an average of 1.8 to 3.7 (out of a possible 5.0). After the course, the individual ratings ranged from 3.5 to 4.8. Considering the entire class, the students' overall knowledge increased from a rating of 2.7 before to 4.2 after. The difference between the students' knowledge levels was significant at the

\begin{tabular}{|c|c|c|c|}
\hline \multicolumn{4}{|c|}{$\begin{array}{l}\text { EXHIBIT } 1 \\
\text { Marketing communication self- } \\
\text { assessment }\end{array}$} \\
\hline $\begin{array}{c}\text { Communication } \\
\text { Tool }\end{array}$ & $\begin{array}{l}\text { Avera } \\
\text { Before }\end{array}$ & $\begin{array}{l}\text { ge Fami } \\
\text { After }\end{array}$ & $\begin{array}{l}\text { liarity } \\
\text { Change }\end{array}$ \\
\hline Situation Analysis & 2.58 & 4.55 & 1.97 \\
\hline Competition Analysis & 3.39 & 4.45 & 1.06 \\
\hline Consumer Research & 3.00 & 4.26 & 1.26 \\
\hline Media Evaluation & 2.32 & 4.32 & 2.00 \\
\hline Public Relations & 2.97 & 4.26 & 1.29 \\
\hline Collateral Material & 2.03 & 4.23 & 2.20 \\
\hline Sales Promotion & 2.81 & 4.39 & 1.58 \\
\hline Direct Mail & 3.29 & 4.39 & 1.10 \\
\hline Outdoor Advertising & 2.68 & 3.84 & 1.16 \\
\hline Telemarketing & 2.61 & 3.61 & 1.00 \\
\hline
\end{tabular}

95-percent confidence level in 29 of 31 cases.

In two cases, students gave themselves lower "after" scores than their "before" scores on some communication tools. Since the students could not have unlearned the material, I believe they either forgot how they rated themselves at the beginning of the course or they learned how little they actually knew about the topic.

Class assessment. Comparison of the class's before and after knowledge of each marketing-communication tool revealed similarly strong results. At the beginning of the course, the average ratings for individual tools ranged from 2.0 (for collateral materials) to 3.4 (for competitive analysis). The range at the end of the course was 3.6 (telemarketing) to 4.6 (situation analysis). Familiarity with individual topics improved by as much as 2.2 points. The difference between the class's "before" and "after" knowledge was significant at the 95-percent confidence level $(p<.01)$ for all ten marketing tools.

\section{Client Comments}

Students and clients were nearly unanimous in their enthusiasm for the experiential approach. Fourteen clients were certain that they benefited from the experience, citing such advantages as new ideas and information, operable strategies, time savings, and increased awareness of 
the importance of marketingcommunications plans. Just one business owner said that the student team had not contributed to the business, while a second owner was unsure of the value of the students' contribution. In that case, the client said the students had good ideas but failed to apply them to the particular business environment.

Students' responses echoed those of the clients. Thirteen student groups said they made a substantial contribution to their clients' businesses. The primary benefit the students cited was imparting increased awareness of marketing issues, especially considering that many clients did not have a formal marketing-communication plan before undertaking this project. Two student groups believed they did not make a valuable contribution and a third was unsure.

There was only one difference of opinion between the client and student assessment of the contribution to the business. The owner of a Collegetown bar and restaurant thought the students' analysis of his establishment was useful because his limited daily contact with the restaurant made it difficult for him to evaluate its operations. The students, however, thought they had made little contribution because the owner is only peripherally involved in the business.

As a final endorsement of the value of the project, 15 out of 16 clients said unequivocally that they would be willing to participate in the course next year. Even the owner who was not favorably impressed said she might participate again if stricter guidelines were developed.

Benefit to Cornell. It seems clear that both students and businesses benefited from the experiential exercise. The university also benefits by providing a service that builds its image in the community.

\section{Course Improvements}

The students' recommendations provided several ideas for improving the course in the future. Many students found that not all communications tools were applicable to their clients. For example, because of local restrictions on billboards and signs, traditional outdoor advertising methods were not feasible for Ithaca merchants. Moreover, some student teams concluded that telemarketing was not technically or economically feasible, especially for small restaurants. In these cases, students suggested that they could by-pass some instruments and develop a more extensive plan using the communications tools best suited to their clients.

While small businesses stand to gain more from this exercise than larger businesses, students concluded that some businesses might be too small to benefit from their suggestions. Course materials were not helpful in this matter, because they concentrated on mid-size organizations with fairly substantial resources and students found it difficult to apply those ideas to small, independent businesses. The students also recommended that the clients be invited to attend the classroom presentations so they could hear commentary from the entire class on the students' strategies.

Limitations. There are three limitations that should be noted when reviewing the comparisons. Differences between the students' before and after ratings may be understated, because students may have overestimated their abilities at the beginning of the course. Some students commented that they learned how little they knew after they had completed portions of the course. Second, the ratings may not be entirely consistent because each student and owner used his or her own set of standards for evaluating knowledge and performance. To ensure a more consistent frame of reference, future measurement systems could include uniformly detailed guidelines for both students and owners. Finally, any implications of this study may be limited by the absence of a control group. Since all students participated in the experiential approach, there was no way to compare their measurements with a similar group of students who had not conducted projects.

Despite these limitations, it is clear that most of the students and businesses profited from the experiential aspects of this course. Students demonstrated significantly increased familiarity with marketing-communications tools. Owners agreed that the communication plans helped their businesses and indicated that they would participate again in the future. Finally, the university gained an opportunity to serve its community and boost its good will.

\section{Differences between the students' before and after ratings may be understated, because students may have overestimated their abilities at the beginning of the course.}

